\title{
Informational support for management decision- making in peripheries of region: problems and development prospects
}

\author{
Elena B. Dvoryadkina, Catherine I. Kaibicheva, Alisa Yu. Titovets \\ Department of Regional - Municipal Economics and Management \\ Ural State University of Economics \\ Ekaterinburg, Russia \\ elena.dvoryadkina@yandex.ru
}

\begin{abstract}
One of the means of increasing the availability of statistics information to local governments are information and analytical systems. The authors analysed and revealed the shortcomings of the current information and analytical systems at the regional and federal levels in Russia. The study of the information needs of local self-government bodies made it possible to conclude that it is necessary to supplement the municipal statistics with new indicators. They can be formed both on the basis of information, received by state statistics bodies within the framework of the existing federal statistical observations, and on the basis of data, included in new forms of static reporting received from enterprises and organizations. In the opinion of the authors, the first of the above-mentioned modes of using the available information is more preferable, since it does not require additional financial and labor costs from the Russian Federal State Statistics Service. In turn, the second mode helps to fill the existing gap in the information required by the authorities and management on the various levels - federal, regional and local. The authors proposed new indicators of municipal statistics, formed using the information on the existing and new forms of federal statistical observation. The figures for calculating new indicators can be drawn from both administrative and census data. The proposed indicators cover three directions of the development of a municipal entity: the economic situation, the state of transport infrastructure and transport communication, the innovative activities of organizations operating in the municipality.
\end{abstract}

Keywords - Information and analytical systems, peripheral urban areas, local government, region.

\section{INTRODUCTION}

For competent management of the development of any territory, the authorities need information that characterizes its economic, demographic, social and other statuses. Peripheries of any region, which usually has its own specific management and economic characteristics, are no exception either. The purpose of this article is to analyze the existing system of information support for managerial decisions in a regional periphery, and to argument the directions for its improvement. For this purpose, the authors tackle problems related to clarifying the concept of "peripheral territory of a region"; analysing their experience of working with information and analytical systems, attempt to pin-point their inherent shortcomings; develop new indicators, based on the information needs of government authorities.

\section{REGIONAL PERIPHERY: CONCEPT AND COMPOSITION}

A regional periphery makes a rather multifaceted object of research. It can include territories remote from the administrative center of a constituent entity of the Russian Federation, or municipal entities having relatively low social and economic development value. The identification of a periphery can also be approached in a more complex way, taking into account not only the geographical position and the level of development, but also other parameters of the territory (population, its innovative activity, "political power", etc.).

The concept of "periphery" is also widely debated in the academic literature. According to D. Wastl-Walter, M. Váradi and F. Veider [1], peripheral and border areas are the same. M. Tykkyläinen gives the following definition: "the frontier area of socio-economic activity, either booming or regressing, is sparsely populated in most cases" [2]. M. Marada and P. Chromý define periphery as "a territory lying outside economically, intensively utilized regions, distinguished by their remoteness from settlement centres, poor transport accessibility and low population density" [3]. J. Sołtys states that "the peripheral areas were not only space outside the metropolitan areas, but also outside the regions of capitals, which are the "national centers for performing some of the metropolitan functions" [4]. The periphery can be seen as "a space element or space portion located on the edge" [5]. Peripherality is very often associated with rural areas [6]. G Nagy, E. Nagy and J. Timár argue that "In the jargon of regional science and planning, discussing the socio-spatial consequences of the transition extensively, periphery has become synonymous with "backwardness", "economically disadvantaged" and "marginality"; while in neoliberal economic discourses, which have gained ground fast, it has come to mean "loser" and "uncompetitive" [7]

A study of the existing approaches to identifying peripheries (table 1), aimed at understanding their essence, allowed the authors to formulate their own vision of what a 
regional periphery is and to identify several aspects the theoretical concept itself.

TABLE I. SCIENTIFIC APPROACHES TO DEFINITION OF PERIPHERY [8], [9]

\begin{tabular}{|c|c|}
\hline Approach & Definition of periphery \\
\hline $\begin{array}{c}\text { The geometric } \\
\text { approach }\end{array}$ & $\begin{array}{l}\text { Areas that are located along the edges of a country } \\
\text { (this concerns border areas) are considered to be } \\
\text { marginal regions. The central factor in determining the } \\
\text { degree of peripherality is, consequently, the distance } \\
\text { from the centre. }\end{array}$ \\
\hline The social approach & $\begin{array}{l}\text { This approach is connected with the marginalization } \\
\text { of social groups, “...whose socialization process has } \\
\text { been somehow disrupted, or to individuals who are } \\
\text { situated outside one particular group or who belong to } \\
\text { various groups simultaneously without being fully } \\
\text { integrated" [10]. }\end{array}$ \\
\hline $\begin{array}{l}\text { The cultural } \\
\text { approach }\end{array}$ & $\begin{array}{l}\text { This approach represents a special form of the social } \\
\text { approach. It is associated primarily with the } \\
\text { segregation of cultural minorities. }\end{array}$ \\
\hline $\begin{array}{c}\text { The economic } \\
\text { approach }\end{array}$ & $\begin{array}{l}\text { Along with the social approach, the economic } \\
\text { approach is one of the most frequently used. This } \\
\text { approach is based on the regional differentiation of } \\
\text { economic activities in a region. An economic } \\
\text { definition of marginality can arise from a number of } \\
\text { varied elements, including natural factors and cultural } \\
\text { and social characteristics of the residents; however, it } \\
\text { is primarily based on economic indicators such as } \\
\text { GDP. }\end{array}$ \\
\hline $\begin{array}{c}\text { The ecological } \\
\text { approach }\end{array}$ & $\begin{array}{l}\text { Areas that are densely populated and considerably } \\
\text { transformed or devastated by human activities are } \\
\text { seen as peripheral. }\end{array}$ \\
\hline $\begin{array}{l}\text { The political } \\
\text { approach }\end{array}$ & $\begin{array}{l}\text { Political marginality is founded, primarily, within a } \\
\text { single country. Territories that are, for whatever } \\
\text { reason, beyond the interest of those, who are entrusted } \\
\text { with decision making power (e.g. national } \\
\text { governments), which brings a series of negative } \\
\text { consequences to these areas, can be labelled. }\end{array}$ \\
\hline
\end{tabular}

Therefore, one can speak about global periphery and national periphery. At the country level, a periphery can be considered "on a small scale - as an outer periphery, i.e., regions and cities located far from the national capital; on a middle-size scale - as an intraregional periphery (districts and towns, municipalities away from the centers of the Russian Federation subjects); on a large scale - as a local periphery (rural areas, at a distance from cities)" [11].

Peripheral territory of a region can be treated as a set of municipal entities thata are remote from the administrative center of the region (subject of the Russian Federation), characterized by a high degree of economic dependence on such center, a comparatively low level of socioeconomic development, the predominance of traditional activities leaning heavily on the available potential of the territory, and where the growth of such potential is largely hampered by the underdeveloped infrastructure [12].

In the authors' opinion, peripheral territories should be characterized in a comprehensive fashion, in several aspects (see Figure 1). In determining the characteristics of peripheral territories of a region one should proceed from the fact that their special feature is the predominant reliance on the factors and conditions of the geographical space within which they are located.

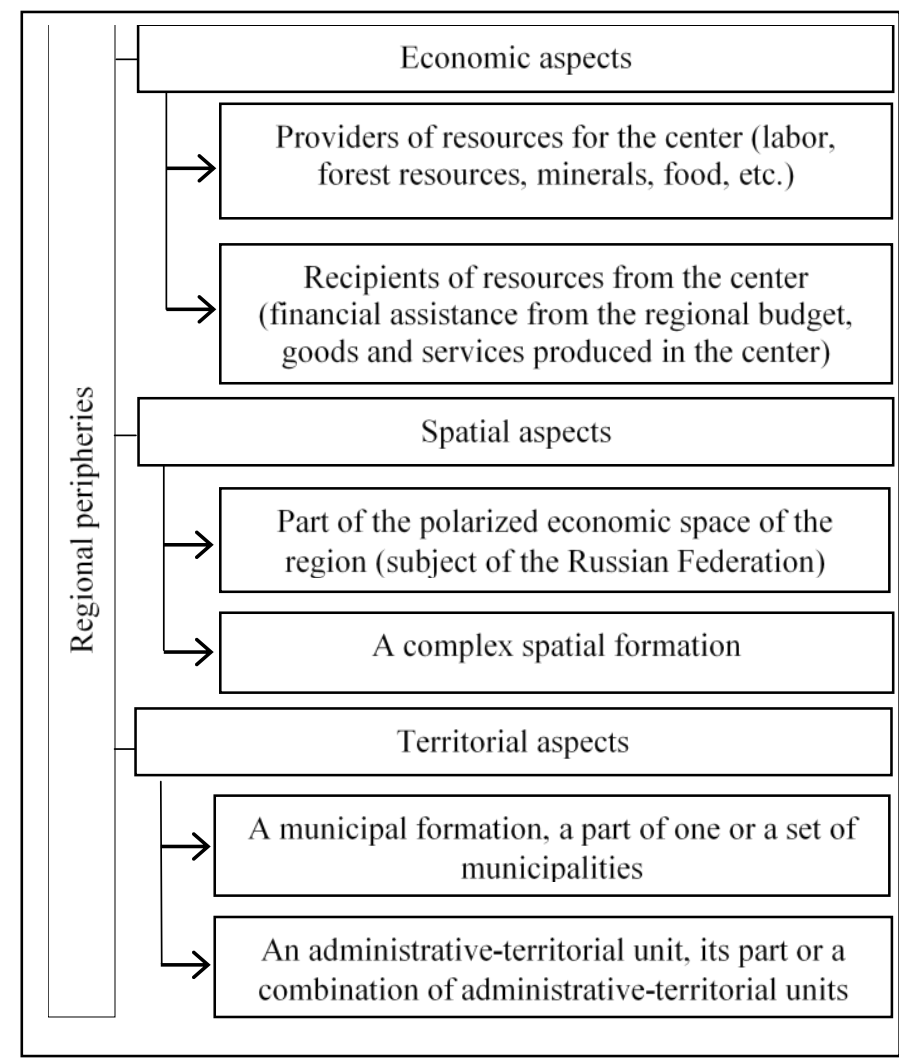

Fig. 1. Aspects of the conceptual term "peripheral territory of a region"

In economics terms, a periphery of a RF subject also acts as a donor of resources (human, natural, etc.) for the center of such subject, and as a consumer of goods and services produced in the center. In addition, peripheral territories can be considered as territorial entities driven by municipal economy, while at the same time possessing features of a peripheral economy.

In territorial terms, peripheral territories represent all or part of territories of a municipal formation or an administrative-territorial unit (city, urban type, etc.).

In terms of human settlement, peripheral territories are the places of residence of the population remote from the administrative center of the region and are urban and / or rural settlements.

In spatial terms, peripheral territories are at the same time part of the economic space of the region and are themselves complex spatial entities. As part of the region's economic space, peripheral territories have the property of being able to change their position in the economic space of the region over time, becoming a semi-periphery, and then, perhaps, a center in their own right. Being spatial entities, peripheral territories possess characteristics inherent in an economic space as such.

Let us consider it possible to talk about the two components of a regional periphery - rural and urban. The former is represented by a set of rural settlements of (one of the types of municipal formations) that meet the criteria mentioned above. The latter includes urban districts and urban settlements, which also meet the requirements. This article 
will concentrate on the urban-settlement peripheries of regions.

\section{PERIPHERY OF A SUBJECT OF THE RUSSIAN FEDERATION AS A MANAGEMENT OBJECT}

Since regional peripheries are represented by municipalities, in accordance with the current Russian legislation, each of the territories has its own bodies of power and administration, including a representative body, head of the municipality, local administration (executive and administrative bodies of the municipality), a control and accounting body, and other bodies provided for by the charter of the municipality [13].

Peripheral municipalities have their own specifics:

- As a rule, a low level of socio-economic development.

- A high degree of economic crisis in the 90s, which has not been overcome so far [14]. Overlapping of the consequences of the 90 s crisis with the more recent 2008 crisis.

- Demographic problems. Decrease of the working age population and population outflow.

The main features of managing the development of peripheral territories are:

- Limited management capabilities associated with the use of financial, economic, labor resources of the territory. Authorities do not have a full set of tools for implementing major projects, and, needing budget subsidies, they largely depend on policies of regional and federal authorities [14].

- Peripheral to the spread of innovation. Diffusion of innovation has a spatial dimension - innovations come later to peripheral areas.

- Low qualification of human resources. Human resource problem is one of the main problems of peripheral territories. It is exacerbated by the outflow of qualified individuals. The problem is especially acute at the level of the administrative apparatus. This is due to the low appeal of the periphery for labor resources in general, as well as low wages in city administrations. As a result, an inefficient administrative apparatus is formed, unable to solve the tasks assigned to it.

- Resources pulled by the center of the region. The problem requires constant attention from the administration, engaged in a veritable struggle for the available resources with the center. For example, creating all kinds of conditions that stimulate the population to live and work in the territory, and not to leave for the center.

- Lack of available information for making competent management decisions in the development of the municipal formation.

Let us dwell in more detail on the last point.

\section{INFORMATION SUPPORT AVAILABLE TO THE AUTHORITIES OF PERIPHERAL TERRITORIES}

One of the problems that local self-government bodies of peripheral urban areas face when addressing local issues is the lack of the necessary statistical information. At present, municipalities solve the problem by requesting information from the territorial bodies of the Federal State Statistics Service, other federal ministries and departments, executive authorities of the constituent entity of the Russian Federation, or by independently collecting the information they need from enterprises, organizations and the public. Here they are faced with the lack of a "legislatively granted right of local selfgovernment bodies to collect statistical data on the development of business and industry in the municipal territory" [15].

One of the ways to improve the information support of the activities of local governments, to optimize their interaction with regional and federal authorities and management has been the creation of information and analytical systems containing information specific to the municipalities.

Currently, the subjects of the Russian Federation use information systems such as the state automated system "Upravlenie" (hereinafter "Upravlenie"), automated systems for managing the activities of the executive bodies of state power of the subjects of the Russian Federation (in particular, in the Sverdlovsk region - an automated system for managing the activities of the executive bodies of the state power in the Sverdlovsk region (hereinafter "ASU IOGV") and other.

Separate systems have been developed by the Federal State Statistics Service - a single interdepartmental information and statistical system (hereinafter "EMISS"), a database of indicators for municipalities (hereinafter the "PMO Database"), and a central statistical database (hereinafter "CBSD").

The available information and analytical systems are not perfect. Among their shortcomings can be noted:

- Inconvenient interface (PMO, EMISS, "Upravlenie");

- Absence of dynamic indicators (in parts PMO, EMISS);

- Lack of data loading for a number of indicators (PMO, EMISS);

- Lack of updates of indicators and lack of data on indicators in recent years (EMISS, CBSD);

- Incorrect work of the website and its lagging/freezing when processing information (PMO);

- The possibility of obtaining more statistical information only if there is an authorized access to the system ("Upravlenie" (the restricted area of the website), IOGV).

In addition, the information contained in the abovementioned systems does not allow us to characterize certain aspects of the development of peripheral urban areas. For example, at present local self-government bodies of peripheral municipal entities do not have information concerning the innovative activity of enterprises and organizations located in 
their territory; their technological development; the cost estimates on trips of the peripheral inhabitants to the center.

Thus, it is obvious that the available information and the analytical systems need improvement, addressing their technical deficiencies and increasing the number of indicators based on the needs of local administrations.

\section{DIRECTIONS FOR IMPROVING THE INFORMATION SUPPORT TO THE AUTHORITIES OF PERIPHERAL TERRITORIES}

The data collected in the framework of various federal statistical observations can already be used today to calculate the indicators that are needed by local authorities and administrations. Approval of official methodologies for calculating various indicators at the municipal levels, amending the Federal Plan of Statistical Works Concerning the Expansion of the List of Indicators of Municipal Statistics (paragraph 1.33 "Municipal Statistics"), uploading new indicators to the existing information and analytical systems (for example, to PMO) will partially solve the problem of the current information deficit.

Several key spheres for peripheral urban areas can be identified, for which it is necessary to develop new indicators in order to improve the information and analytical support to local government bodies.

The first concerns the innovative and technological development of the territories. One of the signs of the periphery is the absence of opportunities for innovation [16].

Using the information, necessary for the assessment of innovative activity of enterprises in peripheral urban areas, one can use the data from the federal statistical observation form No. 4-Innovation "Information on the innovation activity of an organization" (approved by the Order of the Federal State Statistics Service No. 422 of September 25, 2015), No. 2-MP (innovation) "Information on technological innovation of a small enterprise" (approved by the Order of the Federal State Statistics Service of August 3, 2015 No. 357). To characterize the technological development of large and medium-sized enterprises of a municipal formation, one can use the data found in the federal statistical observation form No. 1-Technology "Information on the development and use of advanced production technologies" (approved by the Order of the Federal State Statistics Service of August 5, 2016 No. 391). Surveys using this form target large and medium-sized enterprises of the following economic activities:

- mining and quarrying;

- manufacturing;

- electricity, gas and water supply;

- maintenance and repair of vehicles;

- repair of household and personal items;

- telecommunications;

- other activity related to the use of computers and information technologies;
- activities in the field of architecture, engineering and technical design in industry and construction (in terms of the activities of project and design organizations);

- technical testing, research and certification (regarding testing laboratories and stations);

- higher vocational education;

- news agencies (in the part of the Bureau of Scientific and Technical Information).

According to the mentioned forms of federal statistical observation in the context of municipalities, the following indicators can be calculated:

1) An aggregate level of innovative activity of organizations. The indicator is defined as "the ratio of the number of organizations that carried out technological, organizational or marketing innovations to the total number of organizations surveyed for a certain period of time" [17].

This indicator can be determined separately for large and medium-sized enterprises (source of information - form No. 4Innovation) and separately for small enterprises (source of information - form No. 2-MP (innovation))

Calculation of this indicator will allow one to assess what is the innovative activity of organizations in peripheral territories, and whether there are enterprises that are interested in the development of innovations. The cumulative level of innovative activity of organizations partially characterizes the process of innovations diffusion. When filling out the form "it is assumed that innovative development can be purchased from another enterprise and implemented on the target enterprise (for example, by acquiring licenses for new technologies)" [18].

2) The number of advanced manufacturing technologies, developed at enterprises of the municipality. In accordance with International Recommendations in the field of statistical measurement of science, technology and innovation (Frascati Manual 1993, Moscow, 1995) advanced production technologies are technologies and technological processes (including equipment necessary for their implementation), computer-controlled or microelectronic based and used in the design, manufacture or processing of products (goods and services). The number of advanced manufacturing technologies, developed at enterprises of the municipality, can be calculated by formula (1):

$$
K=\sum_{i=1}^{n} K_{i}
$$

where $\mathrm{K}$ - the number of advanced manufacturing technologies developed at enterprises of the municipality;

$\mathrm{K}_{\mathrm{i}}$ - the number of advanced manufacturing technologies developed at the $i$ municipal enterprise (column 9 line 201);

$\mathrm{n}$ - number of organizations surveyed under form No. 1Technology. It is determined based on the number of completed reports received from organizations.

- research and development; 
Calculation of this indicator will determine whether the development of the peripheral urban area is accompanied by a technological progress. Let us note that this indicator can be calculated separately for industrial enterprises. In this case, the calculations use data obtained from enterprises whose main economic activities are "mining and quarrying", "manufacturing", "electricity, gas and water supply".

One of the signs of a periphery is its transport distance from the administrative center of the region. Therefore, the second direction for improving the information and analytical support to local administrations in peripheral urban areas should be the development of indicators related to the assessment of costs to tackle the distance from the periphery to the center and vice versa.

The total costs that accompany the movement of people and / or goods from the center to the periphery and vice versa can be calculated by formula (2):

$$
c_{i j m}=v_{m} t_{i j m}+c_{m} d_{i j m}
$$

where $\mathrm{c}_{\mathrm{ijm}}$ - the total amount of costs;

$t_{i j m}$ - the journey time between departure point $\mathrm{t}$ and destination $\mathrm{j}$, when using the mode of transport $\mathrm{m}$, in hours;

$d_{i j m}$ - the distance between departure point $\mathrm{t}$ and destination $\mathrm{j}$, when using the mode of transport $\mathrm{m}$, in $\mathrm{km}$;

$v_{m}$ - the value of time, rubles / hour;

$c_{m}$ - costs when using the mode of transport $\mathrm{m}$, rubles $/ \mathrm{km}$.

Resulting indicator $v_{m} t_{i j m}$ can be regarded as a lost profit. For example, for a working citizen, it can be calculated as a product of hourly wages and the duration of the trip.

Indicator $c_{m} d_{i j m}$ can be considered as transportation costs. When using long-distance transport, this figure will be equal to the cost of the ticket. When using personal vehicles, the indicator in the most general form can be calculated as the product of costs (fuel consumption per $1 \mathrm{~km}$ of the route, multiplied by the cost of fuel) and the length of the route.

Calculation of the indicator of total costs can be carried out for different modes of transport. Comparison of the obtained values will allow one to determine which mode of transport is preferable for trips from the center to the periphery and vice versa. Looking at the indicator dynamics, it will be possible to judge whether trips to the center to obtain certain services and to purchase durable goods are becoming more affordable for the inhabitants of the periphery or not.

For example, the indicator can be calculated for the working population of peripheral urban areas. At the same time, the average cost of a trip is determined by the formula of the average arithmetic weighted out of the cost of tickets for intercity buses travelling from the administrative center of the subject of the Russian Federation to the center of the corresponding municipal entity on a weekday. Hourly pay is calculated as a ratio of the average monthly accrued wages of employees to the average number of working days per month in a specific year determined by the Production Calendar with a five-day work week.
An example of calculating the indicator for peripheral urban areas of one of the subjects of the Russian Federation (Sverdlovsk region) is given in Tables 2 and 3. According to Table 3, one can see that the highest indicator values are found for the areas most remote from the center of the region. The costs of residents of the regional capital when visiting the periphery are usually higher (with the exception of the urban district of Pelym), due to higher wages in Ekaterinburg, and, accordingly, a larger amount of lost profits.

TABLE II. INFORMATION FOR CALCULATION OF THE TOTAL COSTS FOR THE CENTRAL AND PERIPHERAL TERRITORIES OF SVERDLOVSK REGION FOR 2014

\begin{tabular}{|c|c|c|c|c|}
\hline $\begin{array}{c}\text { Municipal } \\
\text { unit }\end{array}$ & $\begin{array}{c}\text { Travel time to } \\
\text { Ekaterinburg, } \\
\text { hours }\end{array}$ & $\begin{array}{c}\text { The average } \\
\text { cost of a } \\
\text { trip in an } \\
\text { intercity } \\
\text { bus, rubles }\end{array}$ & $\begin{array}{c}\text { Average } \\
\text { monthly } \\
\text { gross } \\
\text { wage, } \\
\text { rubles }\end{array}$ & $\begin{array}{c}\text { Hourly } \\
\text { rate }\end{array}$ \\
\hline Pelym & 10.1 & 1466.00 & 44892.8 & 267.2 \\
\hline Volchansk & 6.1 & 985.58 & 23643.5 & 140.7 \\
\hline Verkhotursky & 4.3 & 750.00 & 24957.6 & 148.6 \\
\hline Garinsky & 6.7 & $\ldots$ & 23119.3 & 137.6 \\
\hline Novolyalinsky & 4.0 & 666.41 & 21093.6 & 125.6 \\
\hline Sosva & 7.2 & 102600 & 21752.9 & 129.5 \\
\hline Makhnevo & 4.6 & 520.00 & 19317 & 115.0 \\
\hline Tavda & 7.2 & 780.00 & 22606.8 & 134.6 \\
\hline Talitsky & 3.2 & 518.00 & 23330.9 & 138.9 \\
\hline Turinsk & 5.8 & 640.00 & 19894.1 & 118.4 \\
\hline Ekaterinburg & $\mathrm{x}$ & $\mathrm{x}$ & 40224.8 & 239.4 \\
\hline
\end{tabular}

TABLE III. TOTAL COSTS FOR THE CENTRAL AND PERIPHERAL TERRITORIES OF THE SVERDLOVSK REGION FOR 2014, RUBLES

\begin{tabular}{|c|c|c|c|c|}
\hline \multirow[t]{2}{*}{$\begin{array}{c}\text { Municipal } \\
\text { unit }\end{array}$} & \multicolumn{2}{|c|}{$\begin{array}{c}\text { Trips from the } \\
\text { periphery to } \\
\text { the center }\end{array}$} & \multicolumn{2}{|c|}{$\begin{array}{c}\text { Travel from } \\
\text { the center to } \\
\text { the periphery }\end{array}$} \\
\hline & $\begin{array}{l}\text { Loss of } \\
\text { profits }\end{array}$ & Total costs & $\begin{array}{l}\text { Loss of } \\
\text { profits }\end{array}$ & Total costs \\
\hline Pelym & 2698.91 & 4164.91 & 2418.28 & 3884.28 \\
\hline Volchansk & 853.79 & 1839.38 & 1452.56 & 2438.15 \\
\hline Verkhotursky & 643.75 & 1393.75 & 1037.54 & 1787.54 \\
\hline Garinsky & 922.02 & $\ldots^{\text {a) }}$ & 1604.20 & .. $^{\text {a) }}$ \\
\hline Novolyalinsky & 498.04 & 1164.46 & 949.75 & 1616.17 \\
\hline Sosva & 927.95 & 1953.95 & 1715.94 & 2741.94 \\
\hline Makhnevo & 530.83 & 1050.83 & 1105.38 & 1625.38 \\
\hline Tavda & 964.38 & 1744.38 & 1715.94 & 2495.94 \\
\hline Talitsky & 446.71 & 964.71 & 770.18 & 1288.18 \\
\hline Turinsk & 688.79 & 1328.79 & 1392.70 & 2032.70 \\
\hline Ekaterinburg & $\mathrm{x}$ & $\mathrm{x}$ & $\mathrm{x}$ & $\mathrm{x}$ \\
\hline
\end{tabular}

To characterize the economic situation of the municipal formation, the most popular indicator is the gross municipal product - an analog of the gross regional product at the municipal level. The calls to calculate this indicator have been around for a long time. Such calculation would significantly simplify the definition of the socio-economic periphery of a region. Scientists have proposed various methods for its calculation (see, for example, [19]). The position of the official statistics bodies is that the available volume of statistical information in the context of municipalities does not 
allow one to make correctly adjustment calculations similar to those made in calculating the gross regional product (hereinafter "GRP") and, therefore, it is problematic to obtain adequate indicators of the municipal product (see, for example, [20]).

Thus, for the correct calculation of the gross municipal product, it is necessary to conduct additional surveys similar to those that are used in calculating the GRP, allowing one to take into account the structure of the municipal economies.

Another source of information on the social and economic sphere of a municipal formation may be obtained from sociological surveys. With their help, one can assess the living conditions and the quality of life in a given territory, the atmosphere for doing business, etc. Currently, sociological surveys are actively conducted at the level of the subjects of the Russian Federation, for example, with the purpose of assessing the conditions for doing business in the regions of the Russian Federation ("Upravlenie").

Some questions, for example, "Are you ready to change the territory of residence (move to another municipal entity)?" can be included in the census form of the Russian Population Census. The results will show whether this municipal formation is an attractive place to live and whether it has prospects for further development.

\section{CONCLUDING REMARKS}

The management of peripheral territories of the Russian regions is currently complicated by the lack of information necessary for the authorities to make municipal development decisions. In an attempt to solve this problem, various information and analytical systems have been developed at the federal and regional levels. However, the experience of working with these indicates the presence of technical problems, as well as an extensive need for timely updating and uploading of the information. This problem might be solved by integrating the available primary information and the available data in order to calculate additional indicators of municipal statistics. Based on the needs of local selfgovernment bodies of peripheral territories of the Russian regions, the authors proposed indicators characterizing territories' economic, innovative development and transport communication with the regional center. Naturally, the proposed list of indicators does not completely solve the problem of information and analytical support to local government bodies. However, their calculation will allow us to assess certain areas of development of peripheral territories, to clarify the conceptual criteria of a periphery, and to get a clearer look at the composition of the regional periphery itself.

\section{Acknowledgment}

The reported study was supported by Russian Foundation for Basic Research (RFBR), research project No.17-32-00016 "Responses of peripheral urban districts to changes of the parameters of regional economy in conditions of the local government reform"

\section{References}

[1] D. Wastl-Walter, M.M. Váradi, F. Veider, "Coping with Marginality: to stay or to go," Journal of Ethnic and Migration Studies, vol. 29, no. 5, pp. 797-817, 2003.

[2] M. Tykkyläinen, "From territorial marginality to marginality in cybersociety," Perceptions of Marginality: theoretical issues and regional perceptions of marginality in geographical space. Ashgate, Aldershot, pp. 123-132. 1998

[3] M. Marada, P. Chromý, "Contribution to studies on peripheral regions of Czechia," Acta Facultatis Rerum Naturalium Universitatis Comenianae, Geographica Supplementum, no. 2/I, pp. 241-255, 1999.

[4] J. Soltys, "Spatial conditions for development of peripheral areas - the case of northern Poland," 52nd Congress of the European Regional Science Association: "Regions in Motion - Breaking the Path", 21-25 August 2012, Bratislava, Slovakia.

[5] J. Pénzes, "The Dimensions of Peripheral Areas and their Restructuring in Central Europe," Hungarian Geographical Bulletin, vol. 62 (4), pp. 373-386, 2013.

[6] L. Máliková, "Theoretical and methodological aspects of identifying marginal rural areas in the Slovak and Czech studies," Zborník príspevkov medzinárodnej konferencie doktorandov Mendelnet, pp. 459-464, 2013.

[7] G. Nagy, E. Nagy, J. Timár, "The changing meaning of core-periphery relations of a non-metropolitan "urban region" at the HungarianRomanian border," Planning Review, no 48(2), pp. 93-105, 2012.

[8] V. Jančák, T. Havlíček, P. Chromý, S. Kučerová, M. Marada, "Theoretical and methodological aspects of the identification and delimitation of peripheral areas," unpublished.

[9] J. Pileček, V. Jančák, "Theoretical and methodological aspects of the identification and delimitation of peripheral areas," ActaUniversitatisCarolinae, Geographica, vol. 46, no 1, pp. 43-52, 2011.

[10] W. Leimgruber, "Marginality and margional regions: problems of definition," in Chang et al (eds), pp.1-18, 1994

[11] T. Nefedova, The polarization of cities and rural areas and expansion of the Russian periphery. Regional Development and Regional Policy of Russia in Transition Period. Moscow, Publishing House of the MSTU Bauman. 2011.

[12] E.B. Dvoryadkina, C.I. Kaibicheva, and I.I. Shurova, "Compression of Economic Space and its Impact on Peripheral Areas," International Journal of Economics and Financial Issues, vol. 6, Special Issue (S8), pp. 24-29, 2016

[13] On the general principles of the organization of local self-government in the Russian Federation: the federal law of October 6, 2003 No. 131-FZ (as amended on February 15, 2016).

[14] E. Guseva, "The problem of municipal government in small towns," Geoconflictology 2007-2008. http://geoconflict.narod.ru/2008/guseva.html.

[15] The official website of the Association "The Council of Municipalities of the Sverdlovsk Region". URL: http://smo.midural.ru/main/vazhno/300/217.html.

[16] O.V. Gritsay, G.V. Ioffe, A.I. Treyvish. Center and periphery in regional development. Moscow, Nauka, 1991.

[17] The main indicators of innovative activity of organizations in the Sverdlovsk region for 2014: Statistical Bulletin / Territorial Body of the Federal State Statistics Service for the Sverdlovsk Region. Ekaterinburg, 2015.

[18] V. Zinov, A. Sorokina, "Methodical recommendations for teaching the correct filling of the statistical form "№4-innovation"," unpublished.

[19] S.V. Gritsenko, "Statistical estimation of the level of social and economic development of municipalities (on the example of municipal districts of the Voronezh region)", The author's abstract of the dissertation of the candidate of economic sciences. Voronezh, 2009.

[20] N.I. Pashintseva, "On some prospects for the development of regional and municipal statistics," Issues of Statistics, no. 5, pp. 3-5, 2010 